Article

\title{
Intentions to Consume Sustainably Produced Fish: The Moderator Effects of Involvement and Environmental Awareness
}

\author{
Kåre Skallerud ${ }^{1, *}$, John Armbrecht ${ }^{2}$ and Ho Huy Tuu ${ }^{3}$ \\ 1 School of Business and Economics, UiT The Arctic University of Norway, 9037 Tromsø, Norway \\ 2 School of Business, Economics and Law, University of Gothenburg, 40530 Gothenburg, Sweden; \\ john.armbrecht@handels.gu.se \\ 3 Economics Faculty, Nha Trang University, Nha Trang, Vietnam; tuuhh@ntu.edu.vn \\ * Correspondence: Kare.Skallerud@uit.no
}

Citation: Skallerud, K.; Armbrecht J.; Tuu, H.H. Intentions to Consume Sustainably Produced Fish: The Moderator Effects of Involvement and Environmental Awareness. Sustainability 2021, 13, 946 https://doi.org/10.3390/ su13020946

Received: 28 December 2020

Accepted: 15 January 2021

Published: 18 January 2021

Publisher's Note: MDPI stays neutral with regard to jurisdictional claims in published maps and institutional affiliations.

Copyright: (c) 2021 by the authors. Licensee MDPI, Basel, Switzerland. This article is an open access article distributed under the terms and conditions of the Creative Commons Attribution (CC BY) license (https:/ / creativecommons.org/licenses/by/ $4.0 /)$.

\begin{abstract}
The purpose of this study is to apply the conceptual framework of the theory of planned behavior (TPB) to explain the consumption of sustainable produced fish in Sweden. We seek to understand the moderating role of food product involvement and environmental awareness as extensions of traditional constructs such as attitudes, social norms, and perceived behavioral control. The data were derived from a representative sample of 1974 Swedish consumers. Structural equation modeling was applied to test the relationships between constructs and evaluate the reliability and the validity of the constructs. Attitudes had a significantly positive effect on intention to consume fish in general and sustainably produced fish in particular. Social norms had significantly positive effect on intention to consume fish in general, but no effect on intention to consume sustainably produced fish. Behavioral control had no effect on behavioral intention. Interestingly, involvement negatively moderated the effect of attitudes on both intention to consume more fish and to consume more sustainably produced fish. Environmental awareness also negatively moderated the effect of attitudes on intention to consume more sustainably produced fish. It seems that attempts to create food product involvement and environmental awareness among consumers may have the opposite effect-a boomerang effect - than what conventional wisdom and much of the research on fish consumption indicates. Theoretical and practical implications of the findings are discussed.
\end{abstract}

Keywords: fish consumption; sustainability; attitudes; social norms; food product involvement; environmental awareness; Sweden

\section{Introduction}

Fish aquaculture is one $\mathrm{CO}_{2}$-efficient way to cater to the global increased demand for protein [1,2]. Aleksandrowicz et al. [3] estimate that land use and greenhouse gas emissions from food production can be reduced by $70 \%$ and fresh water use by $50 \%$ if current Western diets are based increasingly on fish and seafood instead of meat. Thus, if fish production adheres to existing sustainability standards, such as those proposed by the Aquaculture Stewardship Council (ASC), the negative environmental impacts may be further reduced. Demand-driven levers are one potential force toward increased global fish consumption and thus more sustainable living [4-6].

Understanding the drivers (i.e., antecedents) of consumer behavior in terms of attitudes and preferences, as well as factors moderating their relationship with consumer behavior, is a prerequisite if the aim is to foster more sustainable behavior [7]. Therefore, the purpose of this study was to contribute concerning insights on drivers of consumer behavior in regards to sustainable fish consumption in Sweden through using the theory of planned behavior (TPB) conceptual framework. A version of the TPB framework including attitudes, perceived behavioral control, and social norms are extended by incorporating 
food product involvement and environmental awareness as moderators of the relationship between attitudes and intentions to consume fish in general and more sustainable fish especially.

The theory of planned behavior (TPB) is one of the most widely used theories to predict behavioral intentions in the domains of organic food consumption [8-10], seafood and fish consumption [11-15], and pro-environmental behavior [16-20]. This study contributes by extending the TPB framework to include two moderators: food product involvement and environmental awareness.

Consumers' interest (i.e., involvement) in an activity or a product is pointed out as one central aspect for understanding consumption [21,22]. However, little research has focused on product involvement and fish consumption [23,24]. Verbeke and Vackier [23] used the concept of involvement related to health and found an indirect effect from health involvement through attitudes toward the intention of eating fish. Involvement is suggested as a moderator in the TPB framework in the context of fish consumption [25]. However, how involvement can contribute to theoretical and practical insights to stimulate sustainable consumer demand of fish, leveraging demand-driven green development, is underexplored. Therefore, Carlucci [26] suggests that consumer involvement is an area that should be investigated more in-depth.

Environmental awareness in relation to fish consumption is another construct gaining attention. Preferences in regard to eco-labeled food and packaging techniques may help explain variations in fish consumption [26], especially for consumers driven by environmental consciousness. Eco-labels are a strategy and decision criterion used to activate purchasing behavior among environmentally conscious consumers. Mauracher et al. [27], for example, found that $55 \%$ of their sample were willing to pay a price premium for organic fish. How environmental awareness can contribute to theoretical and practical insights to stimulate sustainable consumer demand of fish, leveraging demand-driven green development, is also underexplored. Therefore, this study included environmental awareness as a moderator in the TPB framework.

The main contributions of this study are reflected in two aspects. First, we explored the moderating effects of food product involvement and environmental awareness in the TBP framework to explain consumption intention toward general fish consumption and sustainable fish consumption in particular. Second, this study was carried out in Sweden, a developed country sometimes referred to as a forerunner in sustainable consumption and environmentalism [28]. Swedes, to a large extent, are convinced that changing consumer behavior is necessary to cope with global environmental problems. The Swedish Environmental Protection Agency states that $89 \%$ of Swedes think of themselves as climateconscious, and most Swedes have taken measures to reduce their climate impact. Therefore, it is of particular interest to study Swedish consumers, being ahead of many other groups of consumers in environmental attitudes and behaviors, to explore important factors to consider in supporting green marketers as they formulate strategies to promote sustainability.

The remainder of the study is arranged as follows. Section 2 provides an overview of the theoretical background. Section 3 presents the research methods and measurements. Section 4 explains the results from the data collected. Sections 5 and 6 elaborate on the main discussions from the findings and draw conclusions.

\section{Conceptual Model and Hypotheses Development}

The theory of planned behavior (TPB) is one of the most widely researched models for predicting behavioral intentions by social psychologists [29-32]. In the domains of food consumption and pro-environmental behavior, the TPB is used as an important theoretical basis to understand consumers' environmentally friendly behavior $[7,16,17,19,20,33,34]$. Within consumer behavior research, behavioral intentions are an accepted predictor of actual behaviors [35-38] and frequently used as a proxy for consumer behavior [34,37]. Behavioral intentions are determined by a person's attitudes toward a product and by the norms affecting that person $[35,38]$. Attitudes and norms may not always be sufficient to 
predict behavioral intentions [36,39], which has been confirmed by Conner et al. [37,40], who found control mechanisms to have an effect on behavioral intentions in the context of healthy diets, for example. The existence of control or regulatory mechanisms suggests that consumption may not always be under volitional control.

\subsection{Attitudes}

Attitudes are used as a proxy of an overall evaluation of a product and reflect the extent to which a person evaluates a product (e.g., fish) to be favorable or unfavorable. In this study, attitudes are used as a proxy of an overall evaluation of fish (including sensory perceptions) and refer to the degree to which individuals judge products to be positive or negative. The more positive consumer attitudes are toward fish, the more likely people will consume it $[14,15,23,24,41]$. Because most studies using attitudes as a predictor within the TPB framework aim to predict behavioral intentions as a proxy for consumer behavior [14,23,38], we propose the following hypothesis:

Hypothesis 1 (H1). Attitudes toward eating fish are positively associated with intention to (a) consume more fish in general and (b) consume more sustainably produced fish.

\subsection{Social Norms}

Individuals' perception about a particular behavior, influenced by the judgment of significant others (e.g., family, friends), is labeled social norms (SN) in the TPB framework. Most often, people want to adhere to existing social norms, which are perceived by individuals as social pressure or expectations $[39,42]$. SN are generally supposed to capture an individual's perception regarding how important others in his or her social environment wish or expect him or her to behave [39,42]. An individual's family is usually regarded as the most important social group to influence consumption behavior. Therefore, this study frames the norm construct in relation to family members' and friends' expectations and pressure to perform particular consumption behavior. We argue that the stronger the norms are that individuals perceive, the more likely it is that a particular behavior will occur. Hence, we hypothesize:

Hypothesis 2 (H2). Social norms are positively associated with intention to (a) consume more fish in general and (b) consume more sustainably produced fish.

\subsection{Perceived Behavioral Control}

Perceived behavioral control (PBC) refers to the perceived ease of performing a behavior and is determined by resources and opportunities. PBC stipulates that people in consumption contexts may not always choose freely, but they are bound to contextual limitations, which shape their choices $[37,39,40]$. Developing perceived behavioral control prior to generating intention is essential. Olsen [40] pointed out that the most important control factors that influence consumers' food purchasing include self-efficacy, convenience, and availability. Many researchers have concluded that confidence in the ability of the individual to control their behavior showed a positive relationship with purchase intention $[43,44]$. Furthermore, perceived behavioral control has been associated with the purchase intention of organic foods $[45,46]$ and green products $[47,48]$. Consequently, the more control an individual has over his or her action (e.g., fish consumption), the more likely consumption will occur, which is formally stated as the following hypothesis:

Hypothesis 3 (H3). Perceived behavioral control $(B C)$ is positively associated with intention to (a) consume more fish in general and $(b)$ consume more sustainably produced fish.

Despite the general usefulness of the TPB, studies continuously make efforts to improve the usefulness and explanatory power of this theory by adding additional constructs $[49,50]$. The present study extends the TPB research model by incorporating food product involvement and environmental awareness to explain fish consumption intentions. 


\subsection{Moderating Effects of Food Products Involvement}

On the basis of Laurent and Kapferer [51], Celsi and Olson [52] defined involvement as a consumer's overall subjective feeling of personal relevance. Involvement thus affects whether a consumer is likely to be more active or passive before, during, and after the consumption moment. Distinctions are made between different types of involvement, i.e., situational and enduring involvement [53], involvement measures treating product categories [54], product involvement, and purchase involvement [55]. In the remainder of the present paper, the concept of involvement refers to food product involvement, since the behavior of interest here is consumers' intention to consume fish products.

Food product involvement affects the evaluation, importance, and choice of products [54]. In a seafood context, Verbeke and Vackier [23] show that food product involvement has a positive relationship with individuals' intention to consume fish. Involvement, defined as "a person's perceived relevance of the object based on inherent needs, values, and interests" [54], therefore has an effect on consumer intentions and behavior [52]. The positive relationship is based on product importance, greater commitment to brands [54,56], and increased self-confidence in food preparation [26]. Carlucci et al. [26] therefore suggest that involvement may explain seafood consumption and constitutes an avenue toward more sustainable consumer practices. Olsen [25], who studied involvement at a product category level related to seafood products, found involvement to have a moderating effect.

On the basis of these previous findings, this study hypothesizes a positive relationship between product involvement and attitudes toward fish consumption. This means that the more involved the consumer is with food, the more positive are his/her attitudes toward eating fish. The aim of the current study is to understand the moderating effect of food product involvement through the following hypothesis:

Hypothesis 4 (H4). Food product involvement moderates the relationship between attitudes toward consuming fish and intention to (a) consume more fish in general and (b) consume more sustainably produced fish. Consumers with higher food product involvement will be more inclined to exhibit favorable intentions toward fish.

\subsection{Moderating Effects of Environmental Awareness}

Consumers may associate fish consumption with adverse environmental and social consequences such as stock exploitation [57] and reduced biodiversity in the oceans from fisheries [58]. Aquaculture has also been linked to negative externalities, such as invasive species [59], degraded ecosystems, diminished water quality, and usage of wild fish species as food for the aquaculture industry [60].

However, due to better food conversion rates, fish consumption has been shown to be less harmful to the environment than for example traditional land-based livestock farming [3]. Consumers who know this fact strive toward higher consumption rates of fish [61]. Often, environmentally aware consumers have positive preferences for cultured fish due to moderate greenhouse emissions [2,3] and land and fresh water consumption [3]. Environmental awareness is an important driver in fish consumption and pertains to the extent to which consumers have knowledge of environmental issues and show their desire or inclination to help solve these issues [62]. In an empirical application, Brécard et al. [63] showed that consumers with high environmental awareness prefer sustainably produced fish (e.g., certified by eco labels) to non-labeled fish. Mauracher et al. [27] stress that consumer preferences may sometimes be ambivalent. The authors showed that $45 \%$ of their sample were not interested in organic certification of fish, while $55 \%$ percent preferred organically certified fish. Previous studies also stress the importance of environmental concern and awareness in predicting environmentally oriented behavior [64,65]. As suggested by Bamberg [17], an individual's environmental awareness indirectly determines specific behaviors. That means that an individual's environmental awareness has an impact on specific behaviors through situation-specific beliefs and attitudes. Since environmental awareness is an important antecedent determining an individual's eco-friendly consump- 
tion behaviors, i.e., to better understand consumers' intentions to consume fish, their environmental awareness will be considered as a moderator of the components of the TPB model. Kushwah [66] found evidence supporting the moderating effect of environmental consciousness on the relationship between consumer value and intentions for more sustainable food consumption. We argue that the level of consumers' environmental awareness and their acceptance of environmentally friendly products can indirectly influence their attitudes toward and intentions to buy fish. We, therefore, outline the following hypothesis related to the potential moderating effect of environmental awareness:

Hypothesis 5 (H5). Environmental awareness moderates the association between attitudes toward consuming fish and intention to (a) consume more fish in general and (b) consume more sustainably produced fish. Consumers with higher environmental awareness will be more inclined to exhibit favorable intentions toward fish.

Figure 1 outlines the hypotheses and provides an overview of the research model. The arrows describe relationships between the constructs, which will be subject to statistical testing.

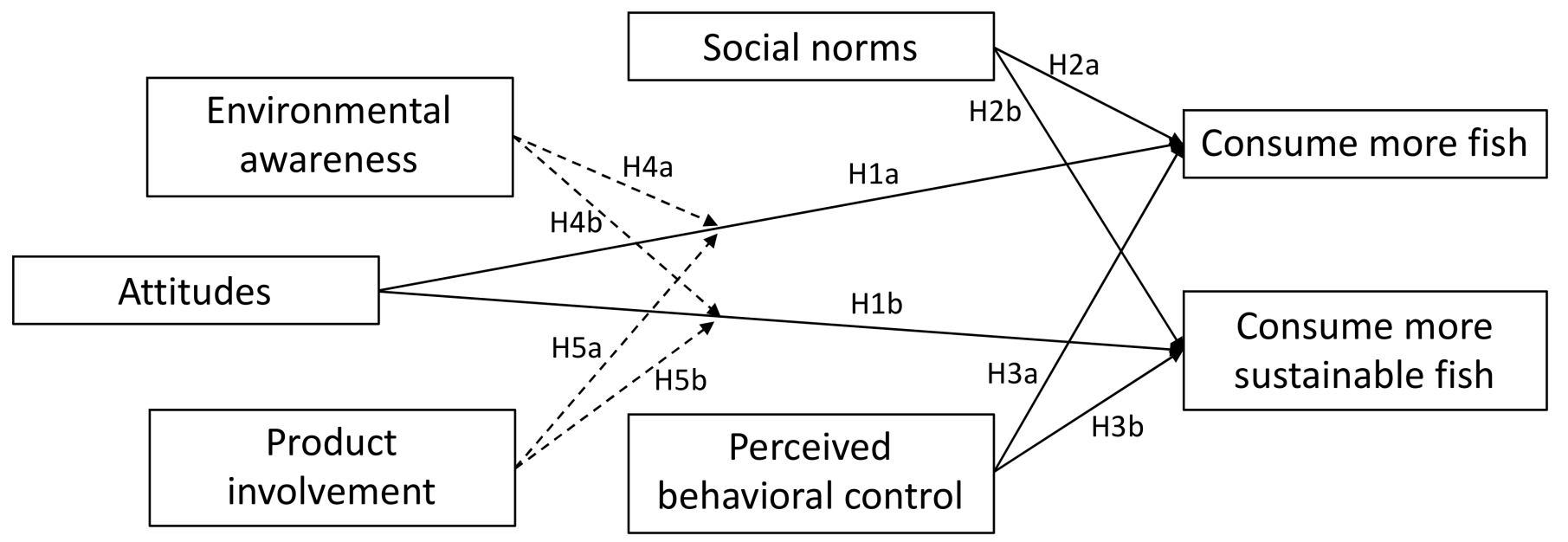

Figure 1. Research model.

\section{Materials and Methods}

The study was carried out in Sweden, a forerunner in sustainable consumption and environmentalism [28]. In a food context, labeled products have penetrated the market, and $98 \%$ of Swedish consumers are aware of the major Swedish eco-label [67]. The trend toward labeling continues to grow and so is sustainable consumption-roughly $60 \%$ state that they tend to buy environmentally friendly products. Bosona and Gebresenbet [68] also show that the consumer segment they labeled as "lifestyle of health and sustainability" increased from $27 \%$ to $38 \%$ between 2005 and 2015 .

\subsection{Data Collection and Sample}

The Laboratory of Opinion Research (LORE), an organization within the University of Gothenburg, which specializes in data collection within social sciences and interdisciplinary research, collected the data from "The Citizen Panel". The panel is mainly used to analyze interests and attitudes toward different subjects in Sweden. In total, the panel includes more than 60,000 active participants on the basis of a probability sample stratified according to age, gender, and education. In total, 3600 respondents were invited to participate in the study, of which 2207 (61.3\%) finalized the survey. A total of 233 responses were deleted due to missing data, rendering a response rate of $54.8 \%(n=1974)$. The sample consisted of $47.7 \%$ females and $52.3 \%$ males. Age groups diverged slightly ( $\pm 3 \%)$ from national statistics. The detailed demographic characteristics of the sample are shown in Table 1. 
Table 1. Demographic characteristics.

\begin{tabular}{ccc}
\hline Characteristics & $\%$ & $n$ \\
\hline Gender & & 1032 \\
Male & $52.3 \%$ & 942 \\
Female & $47.7 \%$ & \\
Age & & 196 \\
$<30$ y & $9.9 \%$ & 281 \\
$30-39$ y & $14.2 \%$ & 334 \\
$40-49$ y & $16.9 \%$ & 354 \\
$50-59$ y & $17.9 \%$ & 454 \\
$60-69$ y & $23.0 \%$ & 355 \\
$\geq 70$ y & $18.0 \%$ & 99 \\
\hline Education & & 998 \\
Primary / lower secondary school & $5.0 \%$ & 877 \\
High school/vocational school & $50.6 \%$ & 354 \\
University degree & $44.4 \%$ & 404 \\
Monthly gross income & & 223 \\
SEK < 16 k & $18.7 \%$ & 379 \\
SEK 16-26 k & $21.1 \%$ & 409 \\
SEK 26-30 k & $11.8 \%$ & 131 \\
SEK 30-37 k & $20.0 \%$ & \\
SEK 37-55 k & $21.6 \%$ & $6.8 \%$ \\
SEK > 55 k & & \\
\hline
\end{tabular}

\subsection{Measurements}

We addressed intention to consume fish in general and consume more sustainably produced fish by two 7-point scale single items: (1) "I plan to eat more fish in the coming month" and (2) "I plan to eat more sustainably produced fish the coming month", coded from completely disagree (1) to completely agree (7). Attitudes toward fish consumption were assessed on an overall level by using 3 integrated items in semantic differential formats [11]. Respondents are presented with the sentence "Eating fish regularly is", and the bipolar adjectives were boring/exciting, unpleasant/pleasant, and unsatisfied/satisfied. The construct of social norms was addressed to include significant others [42] and was measured by 3 statements: "People who are important to me want me to eat fish regularly", "People who are important to me expect that I eat fish regularly", and "People who are important to me encourage me to eat fish regularly". Perceived behavioral control was measured by 3 items. These items assessed internal factors that may be inferred from the performance of the act of consumption [42]. The following questions were asked: (a) "How much personal control do you have over eating fish?"-ranging from no control (1) to complete control (7); (b) "If I wanted to, I could easily eat fish as often as I wanted to"; and (c) "For the most part, it's up to me if I want to eat fish regularly" - with endpoints from completely disagree (1) to completely agree (7). The combination of these items is frequently used to assess the perceived behavioral control within consumer psychology and/or social psychology [69] and food or nutrition behavior [25,70]. Involvement, operationalized as food product involvement, was measured by 4 items using a 7-point scale: (1) "In general, I have a great interest in food"; (2) "Food is very important to me"; (3) "Food means a lot to me"; and (4) "Food is very relevant to me". The items were based on Lee and Yi [71], who constructed their items on the grounding of previous studies by Beatty and Talpade [72]. Environmental awareness related to food was measured using 3 items reflecting identity [73] and the relevance of eco-labeling for decision-making [27]: (1) "When shopping for food, I choose the most environmentally friendly alternative"; (2) "I avoid food items with unnecessary packaging"; and (3) "If there is an environmentally certified alternative, I choose it". The items were coded from completely disagree (1) to completely agree (7). 
Verbeke and Vackier [23] and Olsen [15] found age to be a significant predictor of fish consumption. Older people are more prone to consume fish than younger people are. Significant relationships were also found for age and attitudes [41] and age and involvement. Furthermore, Verbeke and Vackier [23] note that women and high-income groups are more prone to consume seafood than other consumers. Honkanen et al. [14] found significant differences for women, social classes, and income groups with regard to ambivalence and being concerned about wild fish. Kollmuss and Agyeman [74] and Van Liere and Dunlap [75] support findings indicating that women and well-educated people are more likely to pursue green consumption. Socio-demographic variables were therefore included as control variables in our models.

\subsection{Analytical Procedure}

The research model was tested using IBM SPSS Statistics 25 and IBM SPSS Amos 25 Graphics. Confirmatory factor analysis (CFA) was applied to assess the reliability and validity of the factors and measurement items [73]. The chi-squared statistic $\left(\chi^{2}\right)$, the normed chi-square $\left(\chi^{2} / d f\right)$, the goodness of fit index (GFI), the comparative fit index (CFI), and the root mean square error of approximation (RMSEA) were used to assess the model's fit [76-80]. Cronbach's alpha and composite reliability were used to assess the reliability of each construct. Convergent validity and discriminant validity were tested as proposed by Kline [81].

\section{Results}

\subsection{Reliability and Validity of the Measurements}

A model was tested where attitudes, social norms, and $\mathrm{PBC}$ predicted intentions to (1) eat more fish, and (2) eat more sustainably produced fish. The measurement model as outlined in Table 2 was tested in terms of validity and reliability.

Table 2. Standardized factor loadings and reliability of constructs.

\begin{tabular}{|c|c|c|c|c|}
\hline & $\begin{array}{c}\text { Standardized Factor } \\
\text { Loadings }\end{array}$ & $t$-Value & $\begin{array}{l}\text { Composite } \\
\text { Reliability }\end{array}$ & $\begin{array}{l}\text { Variance } \\
\text { Extracted }\end{array}$ \\
\hline Attitudes & & & 0.87 & 0.69 \\
\hline Boring-Exciting & 0.74 & 36.80 & & \\
\hline Unpleasant-Pleasant & 0.87 & 45.57 & & \\
\hline Unsatisfied-Satisfied & 0.88 & 45.79 & & \\
\hline Social norms & & & 0.93 & 0.83 \\
\hline Others want & 0.86 & 47.58 & & \\
\hline Others expect & 0.97 & 57.56 & & \\
\hline Others encourage & 0.89 & 49.81 & & \\
\hline Perceived behavioral control & & & 0.74 & 0.48 \\
\hline Personal control & 0.74 & 30.35 & & \\
\hline If I wanted & 0.68 & 27.95 & & \\
\hline For me to eat fish & 0.67 & 27.65 & & \\
\hline Involvement & & & 0.95 & 0.81 \\
\hline Interest & 0.83 & 45.11 & & \\
\hline Important & 0.93 & 54.62 & & \\
\hline Means a lot & 0.95 & 56.11 & & \\
\hline Relevant & 0.89 & 50.53 & & \\
\hline Awareness & & & 0.84 & 0.65 \\
\hline Environmentally friendly alternative & 0.91 & 47.61 & & \\
\hline Unnecessary packaging & 0.61 & 28.74 & & \\
\hline Certified alternative & 0.86 & 44.24 & & \\
\hline Intention to consume more fish (FI) & $1.00^{\mathrm{a}}$ & Fixed & - & - \\
\hline $\begin{array}{l}\text { Intention to consume more sustainably } \\
\text { produced fish (SFI) }\end{array}$ & $1.00^{\mathrm{a}}$ & Fixed & - & - \\
\hline
\end{tabular}

$$
\chi^{2}=300.7 ; d f=116 ; p=0.000 ; G F I=0.983 ; C F I=0.991 ; R M S E A=0.028 .{ }^{a}=\text { Standardized error is fixed to } 0 .
$$


A confirmatory factor analysis (CFA) based on 18 variables was conducted. On the basis of Jöreskog and Sörbom [82], we found all items to be significant with satisfactory factor loadings (above 0.50). The model fit the data well $\left(\chi^{2}=300.7 ; d f=116 ; p=0.000 ; G F I=0.983\right.$; $C F I=0.991 ; R M S E A=0.028)$ [77]. The statistics supported the one-dimensionality of the constructs $(C F I \geq 0.90)$ [81]. Two different measures of internal consistency or reliability were computed. First, all composite reliabilities were 0.74 or higher, which indicated a degree of internal consistency among the measures that were above the recommended level of 0.60 [79]. Second, except that AVE for PBC was slightly below the target level (0.48), the average variances extracted of most construct measurements were much higher than the suggested level of 0.50 .

The results in Table 3 show that all intercorrelations between the constructs were significant and lower than 0.43 . The discriminant validity of the constructs was tested using the approach suggested by Fornell and Larcker [80]. No squared correlation of the constructs exceeded the square root of the average variance extracted $(A V E)$ from the constructs. We also checked for potential common method bias by using a common method factor approach [83]. The fit of the CFA model with the common method factor was slightly improved $\left(\chi^{2}=211.1 ; d f=99 ; p=0.000 ; R M S E A=0.024 ; G F I=0.988 ; C F I=0.995\right)$ compared with one of the basic measurement CFA models $\left(\chi^{2}=300.7 ; d f=116 ; p=0.000\right.$; $R M S E A=0.028 ; G F I=0.983 ; C F I=0.991)$. However, the factor loadings of the common method factor were all below 0.30 , and the intercorrelations between the constructs were almost unchanged (see Table 3). The results indicate that the common method bias was not problematic. In summary, the measures of the proposed constructs achieved satisfactory reliability and validity.

Table 3. Construct means, standard deviations, and correlations.

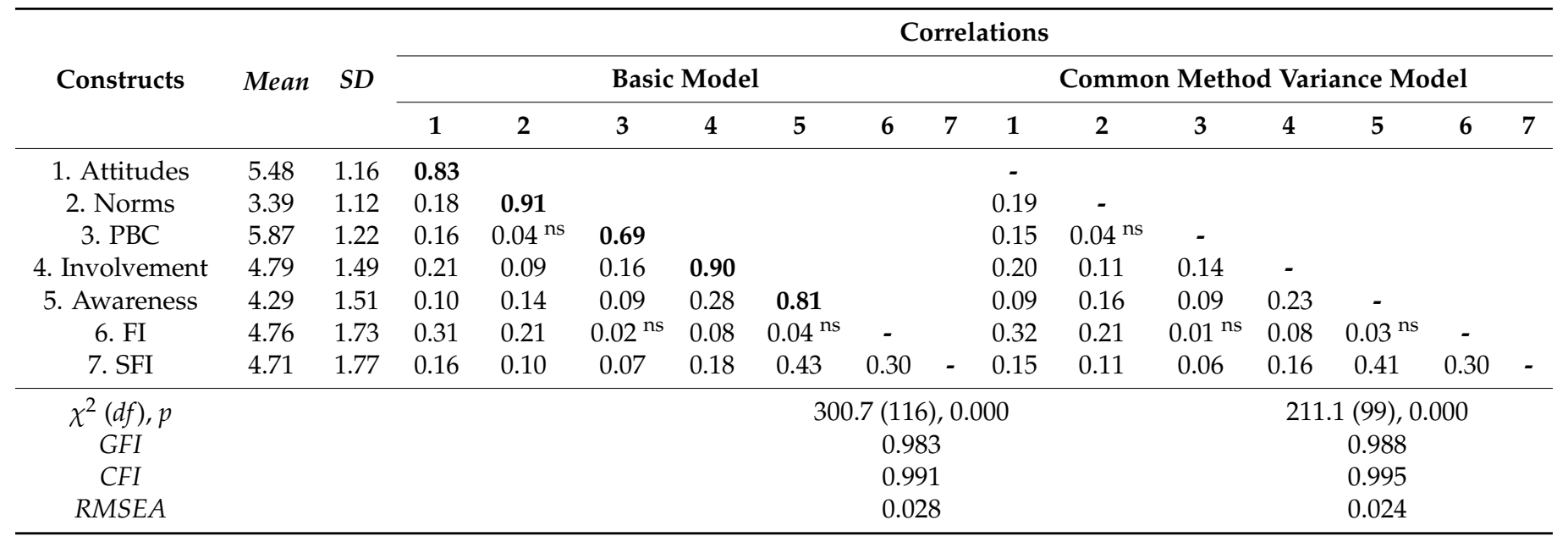

Notes. All correlations are at $p<0.001$; FI: intention to consume more fish; SFI: intention to consume more sustainably produced fish. The bold values in the main diagonal line are the mean root squared of variances extracted of the constructs. ns = non-significant.

\subsection{Testing the Proposed Model}

Having obtained a satisfactory measurement model, we took the next analytical step of testing the direct effect of attitudes, social norms, and PBC and the moderating effect of environmental awareness and involvement on (1) intentions to consume more fish (2) and intentions to consume more sustainably produced fish. Besides the effects of involvement and awareness, individual characteristics (gender, income, education, and age) were included in the model as control variables. We adopted the two-step estimation approach developed by Ping [84] to test the moderator effects. The analytical results in Table 4 show a good fit of the estimated model with the data $\left(\chi^{2}=621.4 ; d f=217 ; p=0.000\right.$; RMSEA $=0.031 ; G F I=0.974 ; C F I=0.982)$. 
Table 4. The hypotheses testing results.

\begin{tabular}{|c|c|c|c|c|c|c|}
\hline \multirow[t]{2}{*}{ Relationships } & \multicolumn{2}{|c|}{$\begin{array}{l}\text { Intention to Consume } \\
\text { More Fish (FI) }\end{array}$} & \multicolumn{2}{|c|}{$\begin{array}{c}\text { Intention to Consume More } \\
\text { Sustainably Produced } \\
\text { Fish (SFI) }\end{array}$} & \multicolumn{2}{|c|}{$\begin{array}{c}\text { Chi-Squared Difference } \\
\text { Test }(d f=1)\end{array}$} \\
\hline & Estimates & $t$-Values & Estimates & $t$-Values & Values & $p$ \\
\hline \multicolumn{7}{|l|}{ Direct effects } \\
\hline Attitudes & 0.29 & $11.79^{* *}$ & 0.12 & $4.98^{* *}$ & 48.64 & 0.000 \\
\hline Norms & 0.17 & $7.42^{* *}$ & 0.03 & 1.31 & 28.44 & 0.000 \\
\hline PBC & -0.04 & -1.47 & 0.01 & 0.51 & 3.05 & 0.081 \\
\hline \multicolumn{7}{|l|}{ Moderating effects } \\
\hline Involvement $\times$ Attitudes & -0.06 & $-2.71^{*}$ & -0.05 & $-2.33 *$ & 0.07 & 0.791 \\
\hline Awareness $\times$ Attitudes & -0.02 & -0.95 & -0.06 & $-2.95 *$ & 5.03 & 0.025 \\
\hline \multicolumn{7}{|l|}{ Controlled effect } \\
\hline Involvement & 0.03 & 1.36 & 0.03 & 1.23 & & \\
\hline Awareness & -0.05 & -1.19 & 0.39 & $16.13^{* *}$ & & \\
\hline Gender & -0.10 & $-4.56^{* *}$ & -0.06 & $-2.79 *$ & & \\
\hline Age & -0.06 & $-2.84 *$ & -0.03 & -1.49 & & \\
\hline Income & 0.03 & 1.18 & 0.01 & 0.50 & & \\
\hline Education & -0.02 & -0.77 & -0.04 & -1.64 & & \\
\hline
\end{tabular}

In terms of direct effects, the test results indicated a positive impact of attitudes on intention to consume more fish $(\beta=0.29, t=11.79, p<0.001)$ and intention to consume more sustainably produced fish $(\beta=0.12, t=4.98 p<0.001)$. Social norms had a significantly positive effect on intention to consume more fish $(\beta=0.17, t=7.42, p<0.001)$ but a nonsignificant effect on intention to consume more sustainably produced fish $(\beta=0.03, t=1.31$, $p>0.10)$. Surprisingly, perceived behavioral control had no effect on intention to consume more fish $(\beta=-0.04, t=-1.47, p>0.10)$ and intention to consume more sustainably produced fish $(\beta=0.01, t=0.51, p>0.10)$.

Interestingly, food product involvement negatively moderated the effect of attitudes on both intention to consume more fish $(\beta=-0.06, t=-2.71, p<0.01)$ and intention to consume more sustainably produced fish $(\beta=-0.05, t=-2.33, p<0.01)$. Environmental awareness also negatively moderated the effect of attitudes on intention to consume more sustainably produced fish $(\beta=-0.06, t=-2.95, p<0.01)$ but not on intention to consume more fish $(\beta=-0.02, t=-0.95, p>0.10)$.

Although we did not hypothesize the relative importance of attitudes, social norms, perceived behavioral control, and the two moderator effects of food product involvement and environmental awareness on the intention to consume more fish versus more sustainably produced fish, exploring whether these relative effects are different is expected to provide deeper insight. Therefore, we conducted an overall chi-squared difference test for all hypothesized direct and moderating effects. Here, a model that imposed equality constraints on all hypothesized effects for both intentions to consume more fish and more sustainably produced fish was compared with the general non-restricted model (i.e., the proposed model). In the second step, we tested the null hypothesis that there was no difference in the direct effects of attitudes, social norms, perceived behavioral control, and the two moderator effects. With five more degrees of freedom $(\mathrm{df}=5)$, the restricted model exhibited a significant chi-squared difference at $p<0.001\left(\chi^{2}=96.58\right)$ from the non-restricted model. Next, we analyzed the specific direct and moderator effects by examining each path pair of the hypothesized effects on intention to consume more fish versus intention to consume more sustainably produced fish. Concerning the findings presented in Table 4 , we found that attitudes $\left(\chi^{2}=48.64 ; p<0.001\right)$ and social norms $\left(\chi^{2}=28.44 ; p<0.001\right)$ influenced differently. Perceived behavioral control $\left(\chi^{2}=3.05 ; p>0.05\right)$ did not differently affect the intention to consume more fish versus more sustainably produced fish. While the moderator effect of involvement was not different $\left(\chi^{2}=0.07 ; p>0.05\right)$, the moderator effect 
of environmental awareness was significantly different between intention to consume more fish and intention to consume more sustainably produced fish $\left(\chi^{2}=5.03 ; p<0.05\right)$.

\section{Discussion}

The purpose of this study was to contribute concerning insights on drivers of consumer behavior with regards to sustainable fish consumption in Sweden, using the TPB conceptual framework. A version of the TPB framework including attitudes, perceived behavioral control, and social norms were extended by incorporating food product involvement and environmental awareness as moderators of the relationship between attitudes and intentions to consume fish in general and more sustainable fish especially.

The results support the application of TPB to explain fish consumption in a Swedish context. The effect from attitudes to intentions is in line with previous research $[9,85]$, thus supporting $\mathrm{H} 1 \mathrm{a}$ and $\mathrm{H} 1 \mathrm{~b}$. Social norms also turned out to be a significant predictor of intention to consume more fish in general, but not for the intention to consume more sustainably produced fish, supporting $\mathrm{H} 2 \mathrm{a}$ and rejecting $\mathrm{H} 2 \mathrm{~b}$. The effect of social norms on intention was weaker than attitudes, however, which is consistent with studies on intention to eat healthy food [40,86] and several other behaviors [29]. Chen and Tung [87] and Chen and Peng [88] indicate that "significant others" are important in consumer decision-making, arguably also regarding fish-more so when it comes to consuming fish in general than consuming sustainably produced fish. We speculate that the reason for this may be that consumers are influenced by significant others to eat fish in general. When it comes to the consumption of sustainably produced fish, we did not see this effect because sustainable consumption is intrinsically motivated rather than extrinsically motivated [89].

Contrary to previous research $[9,87]$, this study found no significant effect from PBC on intentions to consume fish in general and more sustainable fish especially, rejecting $\mathrm{H} 3 \mathrm{a}$ and $\mathrm{H} 3 \mathrm{~b}$. This indicates that varying levels of finding, acquiring, and consuming fish in Sweden does not affect intentions to consume fish and/or sustainable fish. A possible explanation may be that the products are perceived to have high availability, affordability, and familiarity in relation to the product [90].

Although consumption of fish in general and sustainably produced fish in particular offers great potential environmental benefits, the food product involved and environmentally aware consumers seem reluctant to eat more fish even if they have positive attitudes toward fish in general, rejecting $\mathrm{H} 4$ and H5. It seems that attempts to create food product involvement and environmental awareness among consumers may have the opposite effect than what conventional wisdom and much of the research on fish consumption indicates. Richter et al. [7] found a similar boomerang effect. In their study, the descriptive norm interventions (i.e., sustainability labeling interventions in Norwegian and German supermarkets) did not have the intended effect on the proportion of sustainability-labeled seafood sold. Only a negative (boomerang) effect was found for the employed descriptive norm interventions. The success of more sustainable consumption of food in general and seafood in particular requires widespread consumer adoption of such products. Although a shift toward more sustainable food consumption has many benefits, our study shows that consumers are averse to change their behavior.

Both food product involvement and environmental awareness presuppose that the consumer possesses knowledge and information about the specific topic. Maheswaran and Meyers-Levy [91] suggest that the framing effects of information are moderated by subjects' involvement with the framed information. The significant negative effect on intention indicates that increasing levels of environmental awareness render lower levels of sustainable produced fish consumption. Taken together, these findings are important because they indicate that increasing levels of environmental awareness also pose demands on fish products. If fish products are not perceived to be sustainable, then fish consumption is likely to decrease even though consumers have positive attitudes toward fish. The reason is probably that fish in general is not perceived by Swedish consumers to be environmentally sustainable [92]. 
The interaction effect of involvement on attitudes toward intention to consume fish in general and sustainable fish especially was also significantly negative. This can be interpreted as being due consumers with negative attitudes toward fish, but who are highly involved in food products, intending to consume more fish in general and sustainably produced fish in particular. On the other hand, consumers with positive attitudes toward fish and who are highly involved in food products intend to consume less fish in general and sustainably produced fish in particular. This boomerang effect has also been found in other types of persuasive contexts. Therefore, we speculate that efforts to involve consumers with strongly positive attitudes toward fish may decrease consumers' intention to eat more fish. On the other hand, recognizing that some consumers have negative attitudes toward fish, food product involvement can compensate for negative attitudes. Hence, our study provides new insights into the moderating role of both environmental awareness and food product involvement on the relationship between attitudes and intention to consume fish, at least in a Swedish context.

The effects of control variables support the existing research, especially regarding gender differences. Women are more likely to consume fish but are also more inclined toward environmentally sustainable consumption.

\section{Conclusions}

Considerable research points out increasing fish consumption to be one strategy toward reducing the negative environmental effects from food. Increased levels of fish consumption are desirable. This study contributes to the academic research on sustainable consumer behavior by describing what factors explain individuals' fish consumption. The results indicate that individuals' attitudes toward fish and social norms are the main explanatory variables of fish consumption. This means that policies and actions to improve, e.g., the image and perception of fish are promising avenues to increase individuals' consumption of fish. However, at least in a Swedish context, it turns out that food product involvement and environmental awareness moderate the relationship between attitudes toward fish and the intention to eat more sustainably produced fish. The interaction effect is negative. Similar to studies in other empirical contexts, we refer to this effect as a boomerang effect. This study is among the first to report this effect in the context of attitudes toward and intention to consume sustainably produced fish. Experimental applications aiming to describe the effect more precisely need to be conducted. Furthermore, future research should study if this effect is unique for the Swedish context or if similar effects are also existent in other contexts.

From a marketing perspective, the results underline the difficulty in increasing sustainable food consumption in general and fish consumption in particular. The non-linear relationship i.e., boomerang effect of involvement and environmental awareness with consumption means that (potential) consumers cannot be approached with the same messages. The results indicate that companies and public organizations need to adopt different strategies depending on whether they want to market and sell regular fish or sustainably produced fish consumers with varying levels of involvement and environmental awareness. National strategies in Sweden and around Europe exist to increase fish consumption in general, for health reasons and as a means to substitute red meat consumption. The moderating effects of involvement and environmental awareness emphasized that these strategies need to be well adapted and persuasive. Particularly well-informed consumers do not allow themselves to be "fooled" by non-factual marketing tactics. On the other hand, it is also important to educate consumers so that they do not base their choices on myths about fishing, for example, and its sustainability, which is not based on facts. Involvement and environmental awareness were measured through self-assessment in this study. Future studies should extend the findings by comparing the results with the effects of related and complementary concepts such as objective and subjective knowledge. One of the main limitations is the reliance on intentions measured by single items instead of actual behavior. 
Intentions and actual behavior may differ [93]. Future research should also include actual consumption behavior to reduce the potential gap between intention and behavior.

Author Contributions: Conceptualization, K.S. and J.A.; formal analysis, H.H.T.; methodology, K.S. and J.A.; writing—original draft, K.S., J.A. and H.H.T.; writing-review and editing, K.S., J.A. and H.H.T. All authors have read and agreed to the published version of the manuscript.

Funding: This work was supported by a research grant from the Swedish Mariculture Research Centre (SWEMARC) at the University of Gothenburg, Sweden. The publication charges for this article have been funded by a grant from the publication fund of UiT The Arctic University of Norway.

Informed Consent Statement: Informed consent was obtained from all subjects involved in the study.

Data Availability Statement: The data presented in this study are available on request from the corresponding author.

Conflicts of Interest: The authors declare no conflict of interest. The funders had no role in the design of the study; in the collection, analyses, or interpretation of data; in the writing of the manuscript; or in the decision to publish the results.

\section{References}

1. Cahu, C.; Salen, P.; de Lorgeril, M. Farmed and wild fish in the prevention of cardiovascular diseases: Assessing possible differences in lipid nutritional values. Nutr. Metab. Cardiovasc. Dis. 2004, 14, 34-41. [CrossRef]

2. Nijdam, D.; Rood, T.; Westhoek, H. The price of protein: Review of land use and carbon footprints from life cycle assessments of animal food products and their substitutes. Food Policy 2012, 37, 760-770. [CrossRef]

3. Aleksandrowicz, L.; Green, R.; Joy, E.J.; Smith, P.; Haines, A. The impacts of dietary change on greenhouse gas emissions, land use, water use, and health: A systematic review. PloS ONE 2016, 11, e0165797. [CrossRef] [PubMed]

4. Hallstein, E.; Villas-Boas, S.B. Can household consumers save the wild fish? Lessons from a sustainable seafood advisory. J. Environ. Econ. Manag. 2013, 66, 52-71. [CrossRef]

5. Vázquez-Rowe, I.; Villanueva-Rey, P.; Moreira, M.T.; Feijoo, G. The role of consumer purchase and post-purchase decision-making in sustainable seafood consumption. A Spanish case study using carbon footprinting. Food Policy 2013, 41, 94-102. [CrossRef]

6. Dietz, T.; Gardner, G.T.; Gilligan, J.; Stern, P.C.; Vandenbergh, M.P. Household actions can provide a behavioral wedge to rapidly reduce US carbon emissions. Proc. Natl. Acad. Sci. USA 2009, 106, 18452. [CrossRef]

7. Richter, I.; Thøgersen, J.; Klöckner, C. Sustainable seafood consumption in action: Relevant behaviors and their predictors. Sustainability 2017, 9, 2313. [CrossRef]

8. Al-Swidi, A.; Mohammed Rafiul Huque, S.; Haroon Hafeez, M.; Noor Mohd Shariff, M. The role of subjective norms in theory of planned behavior in the context of organic food consumption. Br. Food J. 2014, 116, 1561-1580. [CrossRef]

9. Paul, J.; Modi, A.; Patel, J. Predicting green product consumption using theory of planned behavior and reasoned action. J. Retail. Consum. Serv. 2016, 29, 123-134. [CrossRef]

10. Scalco, A.; Noventa, S.; Sartori, R.; Ceschi, A. Predicting organic food consumption: A meta-analytic structural equation model based on the theory of planned behavior. Appetite 2017, 112, 235-248. [CrossRef]

11. Thong, N.T.; Olsen, S.O. Attitude toward and consumption of fish in Vietnam. J. Food Prod. Mark. 2012, 18, 79-95. [CrossRef]

12. Olsen, N.V.; Sijtsema, S.J.; Hall, G. Predicting consumers' intention to consume ready-to-eat meals. The role of moral attitude. Appetite 2010, 55, 534-539. [CrossRef] [PubMed]

13. Pieniak, Z.; Verbeke, W.; Olsen, S.O.; Hansen, K.B.; Brunsø, K. Health-related attitudes as a basis for segmenting European fish consumers. Food Policy 2010, 35, 448-455. [CrossRef]

14. Honkanen, P.; Olsen, S.O.; Verplanken, B. Intention to consume seafood-The importance of habit. Appetite 2005, 45, 161-168. [CrossRef] [PubMed]

15. Olsen, S.O. Understanding the relationship between age and seafood consumption: The mediating role of attitude, health involvement and convenience. Food Qual. Prefer. 2003, 14, 199-209. [CrossRef]

16. Bamberg, S.; Schmidt, P. Theory-driven subgroup-specific evaluation of an intervention to reduce private car use1. J. Appl. Soc. Psychol. 2001, 31, 1300-1329. [CrossRef]

17. Bamberg, S.; Ajzen, I.; Schmidt, P. Choice of travel mode in the theory of planned behavior: The roles of past behavior, habit, and reasoned action. Basic Appl. Soc. Psychol. 2003, 25, 175-187. [CrossRef]

18. Chen, M.-F.; Tung, P.-J. The moderating effect of perceived lack of facilities on consumers' recycling intentions. Environ. Behav. 2009, 42, 824-844. [CrossRef]

19. Lam, S.-P. Predicting Intentions to conserve water from the theory of planned behavior, perceived moral obligation, and perceived water right1. J. Appl. Soc. Psychol. 1999, 29, 1058-1071. [CrossRef]

20. Terry, D.J.; Hogg, M.A.; White, K.M. The theory of planned behaviour: Self-identity, social identity and group norms. Br. J. Soc. Psychol. 1999, 38, 225-244. [CrossRef]

21. Christy, R.; Oliver, G.; Penn, J. Relationship marketing in consumer markets. J. Mark. Manag. 1996, 12, 175-187. [CrossRef] 
22. Odekerken-Schröder, G.; de Wulf, K.; Schumacher, P. Strengthening outcomes of retailer-consumer relationships: The dual impact of relationship marketing tactics and consumer personality. J. Bus. Res. 2003, 56, 177-190. [CrossRef]

23. Verbeke, W.; Vackier, I. Individual determinants of fish consumption: Application of the theory of planned behaviour. Appetite 2005, 44, 67-82. [CrossRef]

24. Olsen, S.O. Consumer involvement in seafood as family meals in Norway: An application of the expectancy-value approach. Appetite 2001, 36, 173-186. [CrossRef] [PubMed]

25. Olsen, S.O. Repurchase loyalty: The role of involvement and satisfaction. Psychol. Mark. 2007, 24, 315-341. [CrossRef]

26. Carlucci, D.; Nocella, G.; de Devitiis, B.; Viscecchia, R.; Bimbo, F.; Nardone, G. Consumer purchasing behaviour towards fish and seafood products. Patterns and insights from a sample of international studies. Appetite 2015, 84, 212-227. [CrossRef] [PubMed]

27. Mauracher, C.; Tempesta, T.; Vecchiato, D. Consumer preferences regarding the introduction of new organic products. The case of the Mediterranean sea bass (Dicentrarchus labrax) in Italy. Appetite 2013, 63, 84-91. [CrossRef]

28. Isenhour, C. On conflicted Swedish consumers, the effort to stop shopping and neoliberal environmental governance. J. Consum. Behav. 2010, 9, 454-469. [CrossRef]

29. Armitage, C.J.; Conner, M. Efficacy of the theory of planned behaviour: A meta-analytic review. Br. J. Soc. Psychol. 2001, 40, 471-499. [CrossRef]

30. Norman, P.; Armitage, C.J.; Quigley, C. The theory of planned behavior and binge drinking: Assessing the impact of binge drinker prototypes. Addict. Behav. 2007, 32, 1753-1768. [CrossRef]

31. Collins, S.E.; Carey, K.B. The theory of planned behavior as a model of heavy episodic drinking among college students. Psychol. Addict. Behav. 2007, 21, 498-507. [CrossRef] [PubMed]

32. Fielding, K.S.; McDonald, R.; Louis, W.R. Theory of planned behaviour, identity and intentions to engage in environmental activism. J. Environ. Psychol. 2008, 28, 318-326. [CrossRef]

33. Alam, S.S.; Ahmad, M.; Ho, Y.-H.; Omar, N.A.; Lin, C.-Y. Appying an extended theory of planned behavior to sustainable food consumption. Sustainability 2020, 12, 8394. [CrossRef]

34. Wang, B.; Li, J.; Sun, A.; Wang, Y.; Wu, D. Residents' green purchasing intentions in a developing-country context: Integrating PLS-SEM and MGA methods. Sustainability 2020, 12, 30. [CrossRef]

35. Sheeran, P. Intention-Behavior relations: A conceptual and empirical review. Eur. Rev. Soc. Psychol. 2002, 12, 1-36. [CrossRef]

36. Macintosh, G.; Lockshin, L.S. Retail relationships and store loyalty: A multi-level perspective. Int. J. Res. Mark. 1997, 14, 487-497. [CrossRef]

37. Norman, P.; Smith, L. The theory of planned behaviour and exercise: An investigation into the role of prior behaviour, behavioural intentions and attitude variability. Eur. J. Soc. Psychol. 1995, 25, 403-415. [CrossRef]

38. Lim, H.-R.; An, S. Intention to purchase wellbeing food among Korean consumers: An application of the Theory of Planned Behavior. Food Qual. Prefer. 2021, 88, 104101. [CrossRef]

39. Ajzen, I. Consumer attitudes and behavior: The theory of planned behavior applied to food consumption decisions. Rivista di Economia Agraria 2015, 70, 121-138.

40. Conner, M.; Norman, P.; Bell, R. The theory of planned behavior and healthy eating. Health Psychol. 2002, 21, 194-201. [CrossRef]

41. Birch, D.; Lawley, M. The role of habit, childhood consumption, familiarity, and attitudes across seafood consumption segments in Australia. J. Food Prod. Mark. 2014, 20, 98-113. [CrossRef]

42. Ajzen, I. The theory of planned behavior. Organ. Behav. Hum. Decis. Process. 1991, 50, 179-211. [CrossRef]

43. Olsen, S.O. Antecedents of seafood consumption behavior. J. Aquat. Food Prod. Technol. 2004, 13, 79-91. [CrossRef]

44. Baker, E.W.; Al-Gahtani, S.S.; Hubona, G.S. The effects of gender and age on new technology implementation in a developing country: Testing the theory of planned behavior (TPB). Inf. Technol. People 2007, 20, 352-375. [CrossRef]

45. Taylor, S.; Todd, P. Decomposition and crossover effects in the theory of planned behavior: A study of consumer adoption intentions. Int. J. Res. Mark. 1995, 12, 137-155. [CrossRef]

46. Tarkiainen, A.; Sundqvist, S. Subjective norms, attitudes and intentions of Finnish consumers in buying organic food. Br. Food J. 2005, 107, 808-822. [CrossRef]

47. Thøgersen, J. Norms for environmentally responsible behaviour: An extended taxonomy. J. Environ. Psychol. 2006, 26, 247-261. [CrossRef]

48. Moser, R.; Raffaelli, R.; Thilmany, D.D. Consumer preferences for fruit and vegetables with credence-based attributes: A review. Int. Food Agribus. Manag. Rev. 2011, 14, 121-142.

49. Moser, A.K. Thinking green, buying green? Drivers of pro-environmental purchasing behavior. J. Consum. Mark. 2015, 32, 167-175. [CrossRef]

50. Kaiser, F.G.; Scheuthle, H. Two challenges to a moral extension of the theory of planned behavior: Moral norms and just world beliefs in conservationism. Personal. Individ. Differ. 2003, 35, 1033-1048. [CrossRef]

51. Laurent, G.; Kapferer, J.-N. Measuring consumer involvement profiles. J. Mark. Res. 1985, 22, 41-53. [CrossRef]

52. Celsi, R.L.; Olson, J.C. The role of involvement in attention and comprehension processes. J. Consum. Res. 1988, 15, $210-224$. [CrossRef]

53. Richins, M.L.; Bloch, P.H.; McQuarrie, E.F. How enduring and situational involvement combine to create involvement responses. J. Consum. Psychol. 1992, 1, 143-153. [CrossRef]

54. Zaichkowsky, J.L. Measuring the involvement construct. J. Consum. Res. 1985, 12, 341-352. [CrossRef] 
55. Mittal, B. A comparative analysis of four scales of consumer involvement. Psychol. Mark. 1995, 12, 663-682. [CrossRef]

56. Howard, J.A.; Sheth, J.N. The theory of buyer behavior. J. Am. Stat. Assoc. 1970, 65, 1406-1407. [CrossRef]

57. FAO. The State of the World Fisheries and Aquaculture; Food and Agriculture Organization: Rome, Italy, 2014.

58. Worm, B.; Barbier, E.B.; Beaumont, N.; Duffy, J.E.; Folke, C.; Halpern, B.S.; Jackson, J.B.; Lotze, H.K.; Micheli, F.; Palumbi, S.R. Impacts of biodiversity loss on ocean ecosystem services. Science 2006, 314, 787-790. [CrossRef]

59. Naylor, R.L.; Williams, S.L.; Strong, D.R. Aquaculture-A gateway for exotic species. Science 2001, 294, 1655-1656. [CrossRef]

60. Verbeke, W.; Vanhonacker, F.; Sioen, I.; van Camp, J.; de Henauw, S. Perceived importance of sustainability and ethics related to fish: A consumer behavior perspective. AMBIO J. Hum. Environ. 2007, 36, 580-586. [CrossRef]

61. Neff, R.A.; Edwards, D.; Palmer, A.; Ramsing, R.; Righter, A.; Wolfson, J. Reducing meat consumption in the USA: A nationally representative survey of attitudes and behaviours. Public Health Nutr. 2018, 21, 1835-1844. [CrossRef]

62. Dunlap, R.E.; Jones, R.E. Environmental concern: Conceptual and measurement issues. In Handbook of Environmental Sociology; Greenwood: Santa Barbara, CA, USA, 2002; Volume 3, pp. 482-524.

63. Brécard, D.; Hlaimi, B.; Lucas, S.; Perraudeau, Y.; Salladarré, F. Determinants of demand for green products: An application to eco-label demand for fish in Europe. Ecol. Econ. 2009, 69, 115-125. [CrossRef]

64. Kim, Y.; Han, H. Intention to pay conventional-hotel prices at a green hotel-A modification of the theory of planned behavior. J. Sustain. Tour. 2010, 18, 997-1014. [CrossRef]

65. Do Paco, A.; Raposo, M. “Green” segmentation: An application to the Portuguese consumer market. Mark. Intell. Plan. 2009, 27, 364-379. [CrossRef]

66. Kushwah, S.; Dhir, A.; Sagar, M. Ethical consumption intentions and choice behavior towards organic food. Moderation role of buying and environmental concerns. J. Clean. Prod. 2019, 236, 117519. [CrossRef]

67. KRAV. Hållbarhetsrapport 2018 (Sustainability Report 2018); KRAV: Uppsala, Sweden, 2018. Available online: https://www.krav.se/ wp-content/uploads/2019/04/hallbarhetsrapport_2018_webb_lg.pdf (accessed on 26 September 2019).

68. Bosona, T.; Gebresenbet, G. Swedish consumers' perception of food quality and sustainability in relation to organic food production. Foods 2018, 7, 54. [CrossRef]

69. Notani, A.S. Moderators of perceived behavioral control's predictiveness in the theory of planned behavior: A meta-analysis. J. Consum. Psychol. 1998, 7, 247-271. [CrossRef]

70. Sheeran, P.; Orbell, S. Implementation intentions and repeated behaviour: Augmenting the predictive validity of the theory of planned behaviour. Eur. J. Soc. Psychol. 1999, 29, 349-369. [CrossRef]

71. Lee, S.; Yi, Y. "Seize the deal, or return it losing your free gift": The effect of a gift-with-purchase promotion on product return intention. Psychol. Mark. 2017, 34, 249-263. [CrossRef]

72. Beatty, S.E.; Talpade, S. Adolescent influence in family decision making: A replication with extension. J. Consum. Res. 1994, 21, 332-341. [CrossRef]

73. Sparks, P.; Shepherd, R. Self-identity and the theory of planned behavior: Assesing the role of identification with "green consumerism". Soc. Psychol. Q. 1992, 55, 388-399. [CrossRef]

74. Kollmuss, A.; Agyeman, J. Mind the gap: Why do people act environmentally and what are the barriers to pro-environmental behavior? Environ. Educ. Res. 2002, 8, 239-260. [CrossRef]

75. Van Liere, K.D.; Dunlap, R.E. Environmental concern: Does it make a difference how it's measured? Environ. Behav. 1981, 13, 651-676. [CrossRef]

76. Tabachnick, B.G.; Fidell, L.S. Using Multivariate Statistics; Allyn and Bacon: Boston, MA, USA, 2006.

77. Hair, J.F.; Black, W.C.; Babin, B.J.; Anderson, R.E. Multivariate Data Analysis: A Global Perspective, 7th ed.; Pearson Education: Upper Saddle River, NJ, USA, 2010.

78. Jaccard, J.; Jaccard, J.; Wan, C.K. LISREL Approaches to Interaction Effects in Multiple Regression; Sage: New York, NY, USA, 1996.

79. Bagozzi, R.P.; Yi, Y.; Phillips, L.W. Assessing construct validity in organizational research. Adm. Sci. Q. 1991, 36, 421-458. [CrossRef]

80. Fornell, C.; Larcker, D.F. Evaluating structural equation models with unobservable variables and measurement error. J. Mark. Res. 1981, 39-50. [CrossRef]

81. Kline, R.B. Principles and Practice of Structural Equation Modeling; Guilford Press: New York, NY, USA, 2005.

82. Jöreskog, K.G.; Sörbom, D. LISREL 8: Structural Equation Modeling with the SIMPLIS Command Language; Scientific Software International: Lincolnwood, IL, USA, 1993.

83. Podsakoff, N. Common method biases in behavioral research: A critical review of the literature and recommended remedies. J. Appl. Psychol. 2003, 88, 879-903. [CrossRef] [PubMed]

84. Ping, R.A. A parsimonious estimating technique for interaction and quadratic latent variables. J. Mark. Res. 1995, 32, 336-347. [CrossRef]

85. Jonell, M.; Crona, B.; Brown, K.; Rönnbäck, P.; Troell, M. Eco-labeled seafood: Determinants for (blue) green consumption. Sustainability 2016, 8, 884. [CrossRef]

86. Øygard, L.; Rise, J. Predicting the intention to eat healthier food among young adults. Health Educ. Res. 1996, 11, 453-461. [CrossRef]

87. Chen, M.-F.; Tung, P.-J. Developing an extended theory of planned behavior model to predict consumers' intention to visit green hotels. Int. J. Hosp. Manag. 2014, 36, 221-230. [CrossRef] 
88. Chen, A.; Peng, N. Green hotel knowledge and tourists' staying behavior. Ann. Tour. Res. 2012, 39, 2211-2219. [CrossRef]

89. Salonen, A.; Fredriksson, L.; Järvinen, S.; Korteniemi, P.; Danielsson, J. Sustainable consumption in Finland-The phenomenon, consumer profiles, and future scenarios. Int. J. Mark. Stud. 2014, 6, 59-82. [CrossRef]

90. Leek, S.; Maddock, S.; Foxall, G. Situational determinants of fish consumption. Br. Food J. 2000, 102, 18-39. [CrossRef]

91. Maheswaran, D.; Meyers-Levy, J. The influence of message framing and issue involvement. J. Mark. Res. 1990, 27, 361-367. [CrossRef]

92. Rönnerstrand, B.; Armbrecht, J.; Lundberg, E.; Sundell, K. Odlad fisk på tallriken? In Regntunga Skyar; Andersson, U., Carlander, A., Öhberg, P., Eds.; SOM-Institute, Göteborgs Universitet: Gothenburg, Sweden, 2020.

93. Sheeran, P.; Webb, T.L. The intention-Behavior gap. Soc. Personal. Psychol. Compass 2016, 10, 503-518. [CrossRef] 